Uralic studies, languages, and researchers

Edited by Sándor Szeverényi 
Studia uralo-altaica 54

Redigunt:

Katalin Sipőcz

András Róna-Tas

István Zimonyi 
Uralic studies, languages, and researchers

Proceedings of the $5^{\text {th }}$ Mikola Conference 19-20, September 2019

Edited by Sándor Szeverényi

Szeged, 2021 
(C) University of Szeged,

Department of Altaic Studies,

Department of Finno-Ugrian Philology

All rights reserved. No part of this book may be reproduced, stored in a retrieval system, or transmitted in any form or by other means, electronic, mechanical, photocopying, recording or otherwise, without the prior permission in writing of the author or the publisher.

Printed in 2021.

Printed by: Innovariant Ltd., H-6750 Algyő, Ipartelep 4.

ISBN 978-963-306-803-8 (printed)

ISBN 978-963-306-804-5 (pdf)

ISSN 0133-4239 (Print)

ISSN 2677-1268 (Online) 
Table of contents

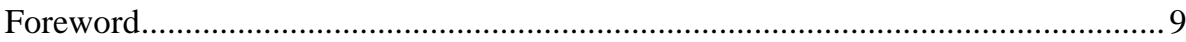

Sándor Szeverényi

Notes on Nicolaes Witsen and his Noord en Oost Tartarye. 11 Rogier Blokland

Undiscovered treasures: From the field research archive to the digital database......27 Beáta Wagner-Nagy, Chris Lasse Däbritz, and Timm Lehmberg

On the language use of the first Finnish medical text 45

Meri Juhos

Sajnovics, the responsible fieldworker 55

Sándor Szeverényi

The life and work of the Saami theologian and linguist: Anders Porsanger 71

Ivett Kelemen

The use and semantics of the Northern Mansi diminutive -riś $r \partial s$ ś 81

Bernadett Bíró

The event of "giving" and "getting" in Siberian Uralic languages 99

Katalin Sipöcz

A word-formational approach to neologisms in modern Northern Mansi

Susanna Virtanen

Word and stem repetitions in the heroic epic songs collected by Antal Reguly ..... 131 Mária Sipos

The use of body part terms in expressing emotions in Udmurt 149

Rebeka Kubitsch

The characteristics of responses given to compliments in Udmurt 173

Zoltán Németh

On some Chuvash-Mari shared lexemes and Agyagási's "Late Gorodets" hypothesis .. 185 Christopher Culver 
“Сувениры Севера" Minority identity and discourse. Representation of indigenous minorities of Northern Russia in the digital media. The case of Dudinka ........... 201 Zsuzsa Várnai and Ágnes Hámori

Reconsidering the Nganasan vowel system 229 László Fejes

New aspects in the study of Mari, Udmurt, and Komi-Permyak: The Typological Database of the Volga Area Finno-Ugric Languages 255 Erika Asztalos, Nikolett F. Gulyás, Laura Horváth, and Bogáta Timár Ethnosyntax in Siberian Uralic Languages (a project report) 275 Bernadett Bíró, Katalin Sipöcz, and Sándor Szeverényi 


\title{
Notes on Nicolaes Witsen and his Noord en Oost Tartarye
}

\author{
Rogier Blokland
}

Uppsala University

\section{Introduction}

Over the last years there has been a quiet upsurge in research on Nicolaes Witsen (1641-1717), intermittent mayor of Amsterdam and author of Noord en Oost Tartarye (henceforth: NOT), a chaotic but fascinating and invaluable tome on the geography, topography, history and ethnography of that vaguely defined region previously known as 'Tartary'. A voluminous Dutch-language biography aimed at the general public was published in 2010 (Peters 2010), nearly 130 years after Gebhard's 1881 biography, which, however, focused on his political career and paid little attention to his 'hobby', i.e. his research on Eurasia. In 2010 a Russian translation of the 1705 edition of NOT was published. Some years before Wim Lucassen (1945-2006), the noted Dutch Abkhazologist and member of the team that had prepared the Russian edition, had suggested that publishing a separate volume on the linguistic material in NOT would be a worthwhile endeavour (cf. Naarden 2018: 2); this resulted in a book (Naarden 2018) with 30 articles of varying length on topics ranging from Witsen's Dutch-Georgian wordlist to Witsen as a western pioneer of Koreanology. It must be pointed out, however, that older sources such as Witsen's diary, published in three volumes in the 1960s (Locher and de Buck 1966-67), though not unknown in our field, are also still able to occasionally yield interesting nuggets of information. The time is therefore ripe, in my opinion, for a new brief overview of Witsen and his NOT.

\section{Witsen's background}

Nicolaas ('Nicolaes' in older Dutch spelling) Witsen came from a well-to-do, powerful, Amsterdam family. His father, Cornelis Janszoon Witsen (1605-1669), had been councillor in the Amsterdam city council, mayor of the city a number of times, and one of the managing directors of the Dutch East India Company (often considered to be the world's first multinational). Due to his important functions Cornelis was immortalized in Bartholomeus van der Helst's painting Banquet of the Amsterdam Civic Guard in Celebration of the Peace of Münster (1648), which can be admired the 
Rijksmuseum in Amsterdam. He was perhaps not a pleasant man, being described as 'a drunk, ... a bloodsucker and a hypocrite' (Schama 1999: 593), and is perhaps best (but unfairly) known for having caused Rembrandt's bankruptcy in 1658 (thus e.g. Schama 1999: 613; Crenshaw 2006: 78). ${ }^{1}$ Growing up in an affluent household, Nicolaes had his own manservant, accompanied his father to England when Cornelis went there to meet Oliver Cromwell (1599-1658), and was given private lessons in 1657 by Jan Comenius (1592-1670), the renowned theologian, philosopher and pedagogue. He also studied law in Leiden where he attended lectures by Jacob Golius (1596-1667), the famous orientalist.

Nicolaas was thus used to power and money from the beginning, and it is then no surprise that he too followed in the Witsen family footsteps and held during his lifetime a number of important positions: he was (like his father Cornelis, nephew Jonas, and his second cousin Johannes Hudde) mayor of Amsterdam (13 times between 1682 and 1706, as at the time one could be mayor for two years within a three-year period), ambassador extraordinary in England, political commissar, delegated councillor, artillery commissar of Amstelveen, Urk en Emmeloord, and, ultimately of significance with regard to his famous opus Noord and Oost Tartarye, board member of the Dutch East India Company (a life-long appointment). This powerful position, in addition to the mayoralty of Amsterdam, was especially useful for him, as through it he gained contacts all over the world who were often to some extent obligated to him and whom he could thus pester for information for his research projects. Thus, for instance, the Dutch sailor Willem de Vlamingh (1640-1698), in an unashamed attempt to flatter his patron, named an island northeast of Kolguyev Island (part of the present-day Nenets Autonomous Okrug) after Witsen, which Witsen immediately added to his 1690 map of Tartary. However, the island later turned out to be non-existent, though it occurs on some other maps of northern Russia (cf. Plate 1); Peters (2010: 92) suggests Vlamingh may have played a practical joke on Witsen.

\footnotetext{
${ }^{1}$ It has recently been shown, however, that this is actually not true, as the loan Rembrandt had contracted for from Witsen was paid out in full out of the sale of movable property, which was sold before Rembrandt was forced to sell his house (Bosman 2019: 118-119).
} 


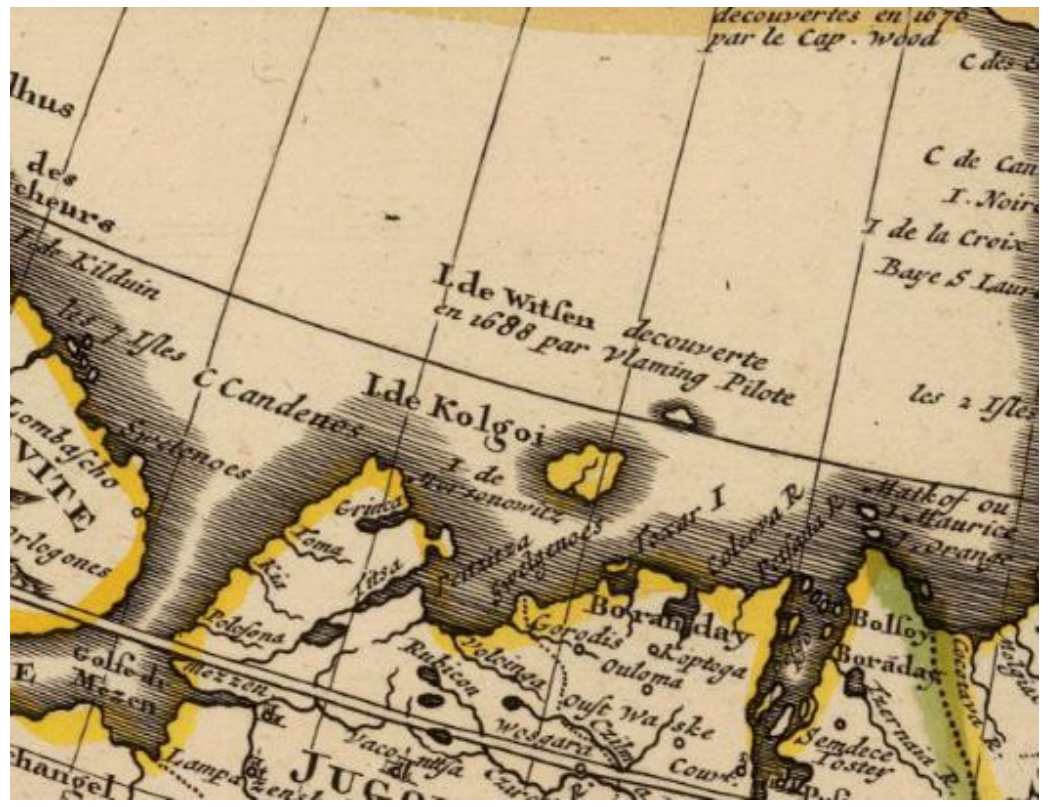

Plate 1. Witsen Island northeast of Kolguyev Island on the 1742 Covens \& Mortier map 'Magnae Tartariae Tabula', based on Guillaume de l'Isle's 1706 map of Tartary.

Witsen is well known for having had extremely varied interests, including history, cartography, astronomy, geography, geology, zoology, botany, epigraphy, and linguistics. These diverse fields may at first sight seem to be completely unrelated to his political pursuits, but in fact they were all connected to his one main interest: the prosperity of the city of Amsterdam. As this was based mainly on trade with other countries, so the more one knew about these, including their history, their physical features, and their inhabitants, the more successful one could be. This had already been advocated by the humanist Casparus Barlaeus (1584-1648), professor of philosophy and rhetoric at the Athenaeum Illustre (the precursor of the University of Amsterdam), who in his 1632 inaugural oration Mercator sapiens asserted that a knowledge of geography, cosmography, ethnology and navigation is of use for merchants and commerce. ${ }^{2}$ The idea, therefore, that merchants and traders could benefit from delving into fields outside of their own purview was already current at the time. Incidentally, the catalogue of Witsen's library (Schouten 1747), which was

2 Cf. Illud ostendam: Optimum esse Mercaturce cum Sapientice ac litterarum studiis commercium, nec augendae rei curam mentis contemplationibus, nec has illi obesse, verum optimis rationibus inter se conspirare, mercandi \& philosophandi facultatem, ut tanto mihi felicior sit futurus mercator, quanto philosophari poterit luculentius. (Barlaeus 1632: 8). 
put on sale in 1747 after his nephew Nicolaes Lambertszoon had died the previous year (Peters 2010: 341), showed Witsen had owned a copy of Barlaeus' oration (Schouten 1747: 14).

Witsen also had a specific interest in Asia in general, again mainly for commercial reasons: was there a northern route to India (by which other nations trading with India could be outmanoeuvred)? Could one draw up a map of Asia with all possible trading possibilities? Closely related to these matters were his religious interests, both practical (the proselytization of 'pagans' in Asia) and theoretical (how did humanity spread from Paradise to such faraway places as Australia?). Logically related to the question about the spread of humanity is the question of the relationship of the world's other languages to Hebrew; in the $17^{\text {th }}$ century it was still generally accepted in Western Europe that Hebrew was the source of all languages.

\section{The mission to Muscovy}

In the late $16^{\text {th }}$ century European trade with Muscovy was mostly in English hands, but due to their access to goods from Asia, Dutch trade with Muscovy started to increase, and by 1600 the Dutch had overtaken the English. There was another increase in Dutch-Russian trade after 1650, and as there was no permanent representative of the Netherlands in Muscovy before 1678, Dutch diplomatic missions were sent there from the 1600 s onwards, especially in order to resolve commercial disputes. It was one of these missions that the young Witsen, 23 at the time, was able to join due to his background as son of the (erstwhile) mayor of Amsterdam. He joined the mission led by ambassador Jacob Boreel (1630-1697) as a 'state nobleman', a title he was given merely to increase the mission's prestige. The mission lasted from 17 September 1664 to 12 August 1665, and comprised 47 members, including also a secretary, an interpreter, a surgeon, assorted noblemen and officers, stewards, a quartermaster, an equerry, grooms, drummers, trumpeters, and pages. The equerry would not return to the Netherlands, as he had his throat cut in Russia (Peters 2010: 37).

Witsen kept a diary during the mission to Moscow, which has its own interesting history. The original is now lost, but in 1668, after his return from Moscow, Witsen gave a copy of it to the French author and scientist Melchisédec Thévenot (16201692) when Thévenot was visiting Amsterdam. Amongst his many other activities Thévenot also published travelogues; this was probably the reason Witsen gave him a copy of the diary. Thévenot later bequeathed it to the Royal Library in Paris, and the diary, which Witsen had never meant to have published, lay there undiscovered ${ }^{3}$ for

${ }^{3}$ E.g. Gebhard, in his biography of Witsen, writes that the diary had been lost (Gebhard 1881: $33)$. 
nearly two centuries, and it was not until 1886, when the library published a catalogue of its Dutch manuscripts (Huet 1886: 49, nos 47-49), that it was (re-)discovered. It was then published in 1966-67 by Theodor Locher and Piet de Buck, but this Dutchlanguage publication received little attention in Uralic circles; Stipa (1990: 46-47) may have been the first to have made use of it. A Latin translation had been planned in the early $18^{\text {th }}$ century, but nothing came of it (Peters 2010: 189), and an edition was planned by the Finnish historian Erkki Kuujo (1921-2004) in the 1950s, but when Kuujo heard of the prospective Dutch edition he selflessly forwent his own project (Locher and de Buck 1966/I: LXXII). A Russian translation ${ }^{4}$ of the diary was published in 1996.

The diary, though it does not describe everything Witsen saw during the voyage to and from Moscow, as it was more meant to be an aide-memoire for himself (cf. Peters 2010: 38), is not unimportant for Uralic studies in that it notes a number of minor facts and occurrences relating to Uralic peoples, which are often either not identical with the information in NOT or not mentioned there at all. For instance, on the $15^{\text {th }}$ of February 1665 Witsen was invited to dinner at an Englishman's residence, where he saw a dance by a group of 'Samoyeds' who had recently arrived in Moscow and describes their features, dress, behaviour, and language ${ }^{5}$ this description is not featured in NOT. Two weeks later, on the $1^{\text {st }}$ of March 1665, a group of Samoyeds also visited ambassador Boreel; Witsen notes they worship 'images' but know of God's existence. ${ }^{6}$

In addition to the diary, among the manuscripts in Paris there are also brief notes ${ }^{7}$ Witsen made in Moscow about Russia in general; this can be seen as the starting point for his subsequent pursuit of collecting information about Eastern Europe, and North and Central Asia. In a description of 'Mordvin Tatars', which Witsen obtained in Moscow in conversation with the Dutch trader Jan van Zweden (d. 1668), he notes

4 The Russian translation was carried out by Wilhelmina Triesman (1901-1982), a Dutch woman who emigrated to Soviet Russia in 1925 and worked as an assistant at the Museum of Anthropology and Ethnology (cf. Jager 2012: 239-240, 248-249, 272).

${ }^{5}$ Dese dan dansten op een been, klapten in hunne handen, sloegen 't hooft op een sonderlinge wyse en songen op haer tael voor ons, dat een belachelyk aanschouwen gaf. 'They danced then on one leg, clapped their hands, hit their heads in a strange manner and sang in their language for us, which was an absurd spectacle' (Locher and de Buck 1966/II: 139).

${ }^{6}$ Se bidden beelden aen, echter weeten van Godt te spreeken; als men wilde sy eens op haer wys soude bidden, wygerde dat: 't selvige geschiet sonts op een vreemde wyse. 'They worship images but know to speak of God; when asked to pray in their own manner they refused: it usually occurs in a strange manner.' (Locher and de Buck 1966/II: 148).

${ }^{7}$ Aentekeningen van saeken mij voorgekomen op myn Moscovische reyse soo van de Russen selve als harens landtsaert 'Notes on matters which occurred during my voyage to Muscovy about the Russians and their character' (Locher and de Buck 1967/III). 
how they, despite being farmers, have 10 to 12 wives each (Locher and De Buck 1967/III: 381); in NOT (1705: 624), however, the text says 'six or seven' wives. There is also a brief description of the Russian Saami (Locher and De Buck 1967/III: 332334), which is completely missing from NOT. A careful comparison of the information in the diary and the notes with the information found in NOT could therefore be a worthwhile undertaking.

In Moscow Witsen also met Andreas Winius (Russian: Андрей Андреевич Виниус; 1641-1717), the son of a Dutch merchant who had emigrated to Russia and (unbeknownst to either) a distant relation; Winius would turn out to be probably the most important of Witsen's contacts in Moscow, as he moved in the highest circles, was rich, spoke both Dutch and Russian natively, and held a number of influential positions, including that of first postmaster general (1675-1701) of Russia, director of the Apothecary Chancellery, and, from 1697 to 1703, chancellor of the Siberian Chancellery. Winius also had the Russian cartographer Semyon Remezov (1642after 1721) compile a map of Siberia, a copy of which Witsen also obtained. A number of letters sent by Witsen to Winius have been preserved (cf. Peters 2010: 106-108), and it is generally assumed that Winius functioned as intermediary who sent Witsen linguistic material on the languages of Russia collected by others. He is never mentioned in NOT, however, probably so that there would be no danger of him being potentially accused of treason (cf. Boterbloem 2013: 72).

It is unlikely that Witsen had already developed all his above mentioned interests during the mission; it is often forgotten that there were exactly 25 years between his return from Moscow and the printing (sic!) of the first edition of NOT (on which more below). He did, however, receive a list of miscellaneous questions to ask in Moscow from Jacob Golius (1596-1667), the abovementioned Orientalist from Leiden (e.g. How far did the Tsar's realm reach to the east of the River Ob? Were there precious metals to be found in Muscovy? How did the Russians mate? Etc.; cf. Peters 2010: 34). The notes accompanying the diary that Witsen gave to Thévenot in 1668 also prove that Witsen had already commenced with his own research during his stay in Moscow: they include a description of 'Samoyeds' that he had received from an Englishman trader from Archangel; this is also included in NOT (1705/II: 895-897), but the inclusion of the description in the notes shows that Witsen already had it by 1668, and, as he travelled back via Novgorod and Riga and did not visit Archangel (cf. Locher and de Buck 1966/I: LXIV-LXV), he must have received it either in Moscow or soon afterwards by post in Amsterdam (Witsen already received his first post from Moscow in 1666; Peters 2010: 102). In contrast to what is occasionally thought, ${ }^{8}$ Witsen made no further trips to Russia or Asia (Peters 2010: 45).

\footnotetext{
8 ‘... voyagea plus loin et pendant de longues années en Russie’ (Muller 1859: 58).
} 


\section{Noord en Oost Tartarye}

After his return from Muscovy he again dedicated himself to his political and civic duties, which he always considered the most significant tasks bestowed on him. He also aimed to compile a map of 'Tartary' and write a commentary to this map: these were supposed to form a cartographic and written overview of trade possibilities in Russia and Asia. Nowadays Witsen is also best known for these printed works, which were in fact the result of his leisure pursuits, and, in a way, mere distractions from the main business of statecraft. In total he wrote five important works: in 1671 Aeloude en hedendaegsche scheeps-bouw en bestier 'Ancient and modern shipbuilding and management', a 556-page richly illustrated description of the history of shipbuilding from the Greeks to the $17^{\text {th }}$ century. It consists of two sections: the first section recites what classical and modern authors have written about the topic, whilst the second section describes the present-day situation. This structure is apparent in NOT too. Aeloude en hedendaegsche scheeps-bouw en bestier was the only book which was actually published in Witsen's lifetime, quickly gaining renown outside the borders of the Netherlands as well: soon after its publication there were already copies in the libraries of well-heeled intellectuals in Sweden, Italy, Russia, and even the Dutch Indies (Peters 2010: 152); a second edition was published in 1690.

Witsen's second important publication is a 1687 map of 'Tartary' (= Siberia and Mongolia). This map, the Nieuwe Lantkaarte Van het Noorder en Ooster-deel van Asia en Europa strekkende van Nova Zemla tot China, has its own intrinsic importance as one of the best foreign maps of Siberia at the time; it is extant today in only 13 copies. It is officially dated to 1687 , but most of the extant copies in the Netherlands are inscribed with a dedication to the tsar 'Peter Alexowitz', who only became tsar in 1696. This is typical for Witsen's working method: his achievements, be they books or maps, would be printed, but not actually published, and he would keep them at home (there being no mundane need for him to earn money through their sale) and continuously improve and refine them, making minute changes whilst constantly acquiring new information. The importance of the map for us lies in the fact that NOT was in fact planned merely as a commentary on this map.

Witsen's third important publication and, undoubtedly, the best known to our readership, is NOT, first published in 1692. As shown by the diary, already in Moscow Witsen had started to establish ties with people with whom he would later correspond, and later this would only increase. The ceaseless flow of information from his global network of informants also had an effect on the structure of NOT: what was at first conceptualized as a supplement and guide to the map of Siberia grew gradually, as Witsen kept adapting and rewriting it, into a fragmented and disorganized work. At the time, however, this was not necessarily seen as a flaw; rather, it was thought that a text was learnèd only if it contained an unending accumulation of facts. 
If we want to be more accurate, we have to say that the 1692 edition was printed but not published, i.e. it was not commercially available. As mentioned above, there was no need for Witsen to sell any of his work, and so his usual mode d'emploi was to print but then keep the actual copies of his work at home. There was also a specific reason for Witsen to not distribute the book, which had to do with the visit in 1697 to the Netherlands by Tsar Peter the Great (incognito, because, according to an ecclesiastical edict, the Tsar was not allowed to leave holy Russian soil). In the Netherlands the Tsar of course met Witsen, mayor of Amsterdam at the time, as it was already known then that Witsen knew a great deal both about Russia and about shipbuilding; this last fact was important as the tsar wanted to make Russia into a naval power. Witsen set himself up as the Tsar's friend, guide, and intermediary, and used the occasion to gather more information about distant lands and exotic peoples from the Tsar's entourage with its hundreds of members and which included both important people such as e.g. Fëdor Alekseevich Golovin (1650-1706), governor of Siberia, and James Daniel Bruce (1669-1735), statesman and general, as well as e.g. Georgian royalty, 'Tartar' slaves, Circassians, and others. The Tsar asked Witsen to continue with his geographical and ethnographical research, which was to have a momentous consequence: Witsen decided then to make many additions to the map, which he had kept at home anyway, also deciding to completely rewrite his book. It was now no longer supposed to be a guide to the map, but rather a compendium of everything known about the lands east of the Urals, though in fact Witsen never restricts himself areally to Asia. This second, much expanded, edition was printed in 1705, in two volumes. Again, the book was printed but not published, and as with the 1692 edition, Witsen kept the actual copies of the book at home and continuously made changes to it; the first edition which was actually published and sold was the second printing of the second edition in 1785, 68 years after Witsen's death, i.e. the first 'public' edition was posthumous. This also explains why there are so few extant copies of the 1692 edition: Witsen did not think it good enough and did not want people to have it. The print run of the 1692 edition is unknown, and Peters (2010: 185) claims that there are only four extant copies (one each in the university libraries of Amsterdam and Utrecht, and two in Moscow: one in the Russian National Library and one in the library of the Academy of Sciences), but a quick online library search has turned up five more: three copies in Germany (one each in Munich in the Bavarian State Library, in Göttingen in the State and University Library, and in Stuttgart in the State Library of Württemberg), one in Paris (in the National Library of France), as well as one in Denmark (in the Royal Library). However, the same fate was to befall the second edition, as here too Witsen never had it sold, and as a matter of fact it was not actually even totally ready in 1705: Witsen was still making changes to the text and to the plates. The date ' 1705 ' therefore does not mean that anybody could have 
possessed a copy in 1705. There were a number of reasons why Witsen did not finish the book: the engraver was slow; Witsen had promised the Tsar a new version of the book but could not send him a copy before a new version of his map was ready (as the book was initially meant to be an accompaniment to the book); as he kept receiving more information from his world-wide network, Witsen just could not stop trying to improve the text, and finally, Witsen felt his strength ebbing in his old age. ${ }^{9}$ It was then only after his death that the existence of a second edition of NOT came to light (cf. Peters 2010: 151).

Because there were so few physical copies of the 1692 and the 1705 editions, the book was in fact not very well known, and it was not completely translated into another language until the 1950s. Jurčenkov (1995: 160), citing Adelung (1864: 206207), claims it was translated into French, German and English, but Adelung in fact observes that it was not translated because it was (a) very big, and (b) written in Dutch. ${ }^{10}$ Tibor Mikola (1936-2000) made a valuable contribution by translating the sections on the Uralic peoples from Dutch into German and publishing these in 1975.

In 2010 a Russian translation of the complete NOT was published in Amsterdam, which also has an interesting history. It was translated from the Dutch into Russian by the aforementioned Wilhelmina Triesman. She was working in the Museum of Anthropology and Ethnography in St. Petersburg in 1945 when she, as a native speaker of Dutch, was asked to translate NOT into Russian in order to make it available for Soviet specialists on Siberia and Asia, using a copy of the book from the library in Leningrad; the very same copy of the book had been used often in the $19^{\text {th }}$ century by German-Russian scientists such as e.g. (the aforementioned) Friedrich von Adelung (1768-1843) and Leopold von Schrenck (1826-1894), whose knowledge of German made it easier to use the book. The (hand-written) translation was finished by 1950 , but in the 1950s the political and ideological climate changed, and publication of a Russian version of NOT was out of the question. However, it could be used by interested scholars, ${ }^{11}$ as the manuscript was registered and available in the library, and

\footnotetext{
${ }^{9}$ In 1713 Witsen writes to his friend Gijsbert Cuper (Peters 2010: 195): De lust is mij hier ook so seer benomen tot de studie door oneyndelijke klijnigheden, die men mij aen heeft gedaen, dat ik er schier onder buck. Echter geeft Godt mij sterkte en tijt van leven, verhope nog iets te doen. 'My desire to continue with my work has been greatly curbed by the infliction of unending trivialities that it weighs heavily upon me. But if God gives me strength and time, I still hope to do something.'

10 'То обстоятельство, что сочинеиіе Витсена, столь важное и любопытное, не было переведено ни на один язык, по истинь возбуждаетъ удивленіе, и можетъ быть объяснено тБмъ только, что оно очень велико, равно и тБмъ, что писано на Голландскомъ языкъ.' (Adelung 1864/II: 207).

${ }^{11}$ Mokšin (1993: 24) is therefore mistaken when he claims in 1993 that there was no Russian translation; the existence of the translation, however, was not generally known.
} 
there were still attempts to have it published in the 1970s, whilst Triesman, Witsenlike, kept on improving the text, doing so even on her deathbed. It was not until 2010, however, 22 years after Triesman's death, that the Russian translation was finally published (cf. Jager 2012: 164-170, 271-274).

\section{The collection of the Uralic material in Noord en Oost Tartarye}

We know very little about when or from whom Witsen received his linguistic material, and, regrettably, the contents of three boxes with all his notes (30 volumes) and practically all letters were mislaid or lost in 1817 (Peters 2010: 13, 19-20). Naarden (2018b: 7) states that Witsen used more than 700 printed, handwritten, and oral sources, ranging from classical authors to letters sent to him from Russia. In NOT he often mentions that he obtained material from a 'friend', and as pointed out above, even the name of Andreas Winius, the friend he had made in Moscow, does not occur in it. Already in Moscow he met, to the extent that it was possible, people he considered interesting (including the Patriarch Nikon of Moscow; cf. Locher and de Buck 1966/II: 267-289), but there is no mention in the diary of any linguistic material collected in Moscow, and it has also been shown with the aid of Witsen's correspondence with Leibniz (cf. Blokland 2018a: 285) that Witsen very likely did not come into the possession of any material in Uralic languages during his stay in Moscow, and that he received the vast majority (if not all) the linguistic material present in NOT by post long after his return to the Netherlands; he received the first letters from Moscow already in 1666 (Peters 2010: 102). None of the Uralic linguistic material in NOT had been previously published, so Witsen must have acquired all of it through his personal contacts. It is sometimes thought that Witsen personally visited areas where Uralic languages were spoken (e.g. Turkin 1993: 278; Mokšin 1993: 2627; Ivanov 2003: 33; Fournet 2008: 13), but Witsen's diary shows that he did not travel further than Moscow.

It is also generally known that the 1692 and the 1705 editions differ as to the Uralic linguistic material they contain: the 1692 edition already contains the DutchMoksha wordlist (which has been analysed already a number of times; cf. e.g. Feoktistov 1959; Feoktistov 1963; Fournet 2008; Maticsák 2012: 39-56; van Pareren and Blokland 2018), but the translations of the Lord's Prayer in Mari, Zyrian Komi, Mansi, Nenets, Enets, Nganasan and Selkup are only found in the second, 1705, edition, and have in general, probably due to their size, received less attention (for recent analyses, see the corresponding articles in Naarden 2018). Here too we do not know who sent these to Witsen; again, we have to be satisfied with typical vague comments such as the one in a letter from Witsen to Leibniz, dated the 9th of April 1699: 'mes amis de Mosco m'écrivent d'avoir reçû quelques autres Oraisons Dominicales, mais qu'à cause des troubles passez \& et de plusieurs autres affaires, ils 
n'avoient pas en du tems pour les faire copier' (Leibniz 1717: 367).

It has also long been recognized that Witsen's interest in wordlists and translations of the Lord's Prayer in the languages of Russia and Asia ensued at least partially from his correspondence with Gottfried Wilhelm Leibniz (1646-1716) (cf. Müller 1955: 6, 17; Stipa 1990: 161; van Hal 2016; Blokland 2018a: 285), and with the German Orientalist Andreas Müller (1630-1694), who had published (under the pseudonym 'Barnimus Hagius') a collection of translations of the Lord's Prayer in 85 languages (Müller 1680; Peters 2010: 261-262); Leibniz ${ }^{12}$ was specifically interested in translations of the Lord's Prayer as comparative material because he thought a comparison of the world's languages could shed light on early human history. The correspondence between Witsen and Leibniz commenced in 1694 (Müller 1955: 6), but we do not know when his correspondence with Müller started; as Müller dedicated a book to Witsen in 1680 (Peters 2010: 331), we can surmise that they must have become acquainted much earlier. We can thus presuppose that Witsen's interest in acquiring such translations was probably inspired by Müller, also because Leibniz' interest in languages in general is reliably assumed to have started only in 1685 (Vermeulen 2015: 68). Interestingly, for a number of the translations of the Lord's Prayer we can narrow down the date Witsen acquired them: it has been shown that Witsen received the translation of the Lord's Prayer in Mari between the $16^{\text {th }}$ of October 1697 and the $5^{\text {th }}$ of July 1699 (Blokland 2018b: 307); for Zyrian Komi and Mansi it could be shown more specifically that Witsen received the translation between the $22^{\text {nd }}$ of May and the $5^{\text {th }}$ of June 1698 (Blokland 2018c: 322).

Similarly, for a translation in a Samoyed language ('l'Oraison Dominicale en Langue Samoyede'), Witsen writes to Leibniz in a letter dated the $21^{\text {st }}$ of July 1698 that he has just received it (Leibniz 1717: 365), and in another letter dated the $5^{\text {th }}$ of July 1699 he writes that he has received two others in 'Samoyed', where Witsen already says that they are different in comparison to the one he already sent, and to each other (Leibniz 1717: 367-368). ${ }^{13}$

Considine (2017: 154) makes the interesting observation that Witsen's Kalmyk wordlist (NOT 1705: 297-304; for a recent analysis, see Badagarov 2018) and the Moksha wordlist were based on the same prompt-list; the Kalmyk wordlist is nearly twice as long as the Moksha one, but many sections have an identical order of Dutch lexical items. Considine therefore assumes that the interpretation of local languages in Russia was in some way centrally coordinated, but it may simply mean that one of

\footnotetext{
${ }^{12}$ Leibniz' interest in language samples, especially from Russia, is well known (cf. Vermeulen 2015: 49; van Hal 2016), although from the 1690s onwards he realized that wordlists are not sufficient for proper language comparison (Müller 1955: 28; Vermeulen 2015: 78).

13 ، ... les deux autres en langue Samojede, toutes deux differentes de celle, que je vous ay cidevant envoiée, \& d'aussi differentes entr'elles, ...'
} 
Witsen's Russian contacts sent the same list to different local collectors. Another interesting fact with regard to the Kalmyk and Moksha wordlists is that the translation amidu for Dutch leeft ('is alive') in the Moksha wordlist (cf. NOT 1705: 625) is in fact Kalmyk (cf. Kalmyk emd 'alive', Written Mongolian amidu 'id.', Written Oirat amidu 'id.'; Badagarov 2018: 489). The mistake may have been made by Witsen, or the mixup may already have occurred before the letters with the Moksha and Kalmyk material reached him. It has already been shown (cf. Badagarov 2018 for Kalmyk) that much of the material was mediated via Russian, but despite his interest in languages, ${ }^{14}$ Witsen's own language knowledge was not very impressive: he read Greek with difficulty, could write some Latin, spoke French and English, but not very well (Peters 2010: 253; Naarden 2018b: 9). ${ }^{15}$ In Moscow he attempted to learn Russian but was not allowed to do so, and could only attain some elementary knowledge of the language (cf. Locher and de Buck 1966/I: LXI). It is thus not surprising, both due to the convoluted route the material was sent to Witsen and because of his modest knowledge of Russian and its alphabet, that there are many inaccuracies and misinterpretations in the translations.

\section{Conclusion}

Noord en Oost Tartarye is a fascinating book, though it is not an easy read. As Müller (1733: 216-217) states, it seems as if Witsen added bits and pieces to his magnum opus as and when he received them. ${ }^{16}$ For a number of reasons (his wealth, his worry that he might be plagiarized, his promise to Tsar Peter the Great, his unending efforts to improve his book, the language it was written in, and ultimately his failing health) led to NOT not being made commercially available and therefore not as well-known as it could have been. The Russian translation, carried out more than 50 years ago by Wilhelmina Triesman in the Soviet Union in extremely difficult circumstances, has now finally seen the light of day, and its availability both as a printed book (Witsen 2010) as well as an online Dutch-Russian bilingual edition (Witsen 2015) will hopefully cause a renewed interest in Witsen's work, as there still remain many unanswered questions.

${ }^{14}$ His library included more than 50 dictionaries and more than 40 grammars of languages ranging from Chinese to Syriac (Schouten 1747; Peters 2010: 360).

15 Jorink (2010: 327) claims that Witsen 'studied Greek, Coptic, Arabic, Turkish, Aramaic and cuneiform, as well as more contemporary languages such as Hottentot, Kalmuk (= Kalmyk) and Samoyed', but this is undoubtedly a misunderstanding.

16 'Ausser dieser General-Eintheilung ist im Wercke fernerhin keine Ordnung anzutreffen. Die weitläuffigsten Beschreibungen und Rapporten, worin offtmahls von gantz unterschiedenen Materien gehandelt worden, sind in Forma eingerücket, und es scheinet nicht selten, als habe sich der Verfaszer in Mittheilung derselben blos nach der Zeit des Empfangs gerichtet.' 


\section{References}

Adelung, Friedrich (von) 1864. Kritiko-literaturnoe obozrenie putešestvennikov po Rossii do 1700 goda i ikh sočinenij. Čast' II. Moskva.

Badagarov, Jargal 2018. Witsen's Kalmyk glossary. In: Naarden 2018: 461-538.

Barlaeus, Casparus 1632. Mercator sapiens, sive oratio. Amsterdam: Guillielmus Blaeu.

Blokland, Rogier 2018a. IV. Finno-Ugric languages. Introduction. In: Naarden 2018: 283-288.

Blokland, Rogier 2018b. The Lord's Prayer in Mari. In: Naarden 2018: 305-317.

Blokland, Rogier 2018c. The Lord's Prayer in Zyrian Komi. In: Naarden 2018: 319334.

Bosman, Machiel 2019. Rembrandts plan. De ware geschiedenis van zijn faillissement. Amsterdam: Athenaeum-Polak \& Van Gennep.

Boterbloem, Kees 2013. Moderniser of Russia. Andrei Vinius 1641-1716. Houndmills: Palgrave Macmillan.

Considine, John 2017. Small dictionaries and curiosity. Lexicography and fieldwork in post-medieval Europe. Oxford: Oxford University Press.

Crenshaw, Paul 2006. Rembrandt's bankruptcy. The artist, his patrons, and the art market in seventeenth-century Netherlands. Cambridge: Cambridge University Press.

Feoktistov, Aleksandr P. 1959. Esimene mordva sõnastik. Emakeele Seltsi aastaraamat 5: 268-287.

Feoktistov, Aleksandr P. 1963. Mordovskie jazyki i dialekty v istoriko-ètnografičeskoj literature XVII-XVIII vv. Koljadënkov, M.N. (ed). Očerki mordovskikh dialektov. Tom II. Saransk: Mordovskoe knižnoe izdatel'stvo. 3-36.

Fournet, Arnaud 2008. Le vocabulaire mordve de Witsen. Une forme ancienne du dialecte Zubu-Mokša. Études Finno-Ougriennes 40: 1-26.

Gebhard, Johan Fredrik 1881. Het leven van Mr. Nicolaas Cornelisz. Witsen (16411717). I. Levensbeschrijving. Utrecht: J.W. Leeflang.

van Hal, Toon 2016. Leibniz, das Vaterunser und die Sprachvielfalt. In: Grötschel, Martin et al. (eds). Vision als Aufgabe: das Leibniz-Universum im 21. Jahrhundert. Berlin: Berlin-Brandenburgische Akademie der Wissenschaften. 255-264.

Huet, Gédéon 1886. Catalogue des manuscrits néerlandais de la Bibliotheque Nationale. Paris.

Ivanov, Ivan G. 2003. Marij literatur jâlme istorij. Joškar-Ola: Marij kugâžanôšs universitet.

Jager, Janine 2012. Wilhelmina Triesman 1901-1982. Een Nederlandse in Leningrad. Amsterdam: Pegasus. 
Jorink, Eric 2010. Reading the book of nature in the Dutch Golden Age, 1575-1715. Brill's Studies in Intellectual History, vol. 191. Leiden and Boston: Brill.

Jurčenkov, Valerij 1995. Vzgljad so storony. Mordovskij narod i kraj v sočinenijakh zapadno-evropejskikh avtorov VI-XVIII stoletij. Saransk: Mordovskoe knižnoe izdatel'stvo.

Leibniz 1717 = von Eckhart, Johann Georg (ed) 1717. Illvstris Viri Godofr. Gvilielmi Leibnitii Collectanea Etymologica, Illvstrationi Lingvarvm, Veteris Celtica, Germanica, Gallica, Aliarvmqve Inservientia. Pars II. Hanoverae: Foerster.

Locher, Th. J. G. and Buck, P. de (eds.) 1966-1967. Nicolaas Witsen. Moscovische reyse 1664-1665: journaal en aantekeningen. I-III. Werken der Linschoten Vereeniging LXV1-LXVIJI. 's-Gravenhage: Martinus Nijhoff.

Maticsák, Sándor 2012. A mordvin írásbeliség kezdetei (XVII-XVIII. század). Debrecen: Debreceni Egyetemi Kiadó.

Mikola, Tibor 1975. N. Witsens Berichte über die uralischen Völker. Studia UraloAltaica VII. Szeged: Universitatis Szegediensis de Attila József nominata.

Mokšin, Nikolaj F. 1993. Mordva glazami zarubežnykh i rossijskikh putešestvennikov. Saransk: Mordovskoe knižnoe izdatel'stvo.

Muller, Frederik 1859. Essai d'une bibliographie neerlando-russe. Catalogue d'une collection remarquable de livres, atlas, cartes, portraits, planches, manuscrits hollandais, et de plusieurs livres étrangers, tous concernant la Russie et la Pologne. Amsterdam: Frederik Muller.

Müller $1680=$ Orationis Dominicae versiones fermè centum. Oratio Orationum. $S$ S. Oratiois Dominicae Versiones proter Authenticam ferè Centum eceque longé emendatiùs quàm antehàc et è probatissimis Auctoribus potius quàm prioribus Collectionibus, Jamque singula genuinis Linguce suce characteribus adeòque magnam partem ex are ad editionem à Barnimô Hagiô traditce, editceque à Thoma Ludekenio, Solqv. March. Berolini, Ex Officina Rungiana, Anno 1680.

Müller, Gerhard Friedrich 1733. Nachricht von einem raren Wercke betitult: Noorden Oost-Tartarye durch Nicolaes Witsen. In: Müller, Gerhard Friedrich. Sammlung Russischer Geschichte 1(3). Sankt-Petersburg: Kayserl. Academie der Wissenschaften. 196-221.

Müller, Kurt 1955. Gottfried Wilhelm Leibniz und Nicolaas Witsen. Sitzungsberichte der Deutschen Akademie der Wissenschaften zu Berlin. Klasse für Philosophie, Geschichte, Staats-, Rechts- und Wirtschaftswissenschaften. Jahrgang 1955, nr. 1. Berlin: Akademie-Verlag.

Naarden, Bruno et al. (eds) 2018. The fascination with Inner Eurasian languages in the 17th century. The Amsterdam mayor Nicolaas Witsen and his collection of 'Tartarian' glossaries and scripts. Amsterdam: Pegasus.

Naarden, Bruno 2018b. Historical introduction: In: Naarden 2018: 5-60. 
van Pareren, Remco and Blokland, Rogier 2018. The Dutch-Mordvin glossary. In: Naarden 2018: 289-303.

Peters, Marion 2010. De wijze koopman. Het wereldwijde onderzoek van Nicolaes Witsen (1641-1717), burgemeester en VOC-bewindhebber van Amsterdam. Amsterdam: Bert Bakker.

Schama, Simon 1999. Rembrandt's eyes. London: Allen Lane.

Schouten, Salomon 1747. Bibliotheca nitidissima sive catalogus librorum, theologicorum, juridicorum, historicorum, philosophicorum, de hist. naturali scriptorum, numismaticorum, antiquariorum, \& miscellaneorum [...]. Quibus, dum vixit, Usus est Vir Nobilissimus atque Amplissimus Nicolaus Witsen, Senator \& Judex Reipublicae Amstaelodamensis. Quorum omnium publica Auctio habebitur in Aedibus Salomonis Schouten, in platea vulgo de Kalverstraat, ad Diem Lunae 20 Martii \& seqq. Anni 1747. Amsterdam: Salomon \& Petrus Schouten.

Stipa, Günther Johannes 1990. Finnisch-ugrische Sprachforschung. Von der Renaissance bis zum Neupositivismus. Mémoires de la Société FinnoOugrienne 206. Helsinki: Suomalais-Ugrilainen Seura.

Turkin, Adol'f I. 1993. Ob odnom maloizvestnom pamjatnike drevnepermskom pis'mennosti. In: Festschrift für Raija Bartens zum 25.10.1993. Mémoires de la Société Finno-Ougrienne 215. Helsinki: Suomalais-Ugrilainen Seura. 277281.

Vermeulen, Han F. 2015. Before Boas. The genesis of ethnography and ethnology in the German enlightenment. Lincoln \& London: University of Nebraska Press.

Witsen, Nicolaes 1705. Noord en Oost Tartarye, ofte Bondig Ontwerp van eenige dier Landen en Volken, welke voormaels bekent zijn geweest, beneffens verscheide tot noch toe onbekende, en meest nooit voorheen beschreve Tartersche en Nabuurige Gewesten, Landstreeken, Steden, Rivieren, en Plaetzen, in de Noorder en Oostelykste Gedeelten van Asia en Europa (2 vols.). Amsterdam: François Halma.

Witsen 2010 = Vitsen, Nikolas 2010. Severnaja $i$ vostočnaja Tatarija I-III. Amsterdam: Pegasus.

Witsen $2015=\underline{\text { http://resources.huygens.knaw.nl/retroboeken/witsen/ }}$ 